\title{
Internal Vs External Locus of Control: The Better Option for Maximization of Students’ Academic Performance
}

\author{
Alfred, Dakoru Osomkume (Ph.D)*, Uduak Idoghor \\ Department Of Curriculum Studies and Educational Technology, Faculty of Education, University of Port \\ Harcourt, Choba, Port Harcourt, Nigeria.
}

*Corresponding Author: Alfred, Dakoru Osomkume (Ph.D), Department Of Curriculum Studies and Educational Technology, Faculty of Education, University of Port Harcourt, Choba, Port Harcourt, Nigeria.

\begin{abstract}
This paper explored internal and external loci of control. Internal locus of control was critically examined vis a vis external locus of control. Owing to the strength internal locus of control weighs over external locus of control, the paper therefore presents the former as a better locus which will help students perform better in their academics. Furthermore, the paper ex-rayed some features associated with students with internal locus of control and those associated with external locus of control. It also critically examined both loci and advanced their implications for students' academic performance. It was concluded that internal locus of control was a better alternative than external locus of control. Therefore, students were advised to cultivate internal locus of control in order to maximize their performance academically.
\end{abstract}

\section{INTRODUCTION}

Education is a process which results in a product. There must be a change in the behaviour of learners if they claim that they have actually acquired education. However, it has been observed that many students who claim to be educated fall short of societal requirements or expectations.

In Nigeria, there are many graduates who are bereft of the knowledge power required of them. Many students have several reasons to give why they do not do well academically. Some blame the system, the environment, their teachers, the country, to mention a few. The society does not accept any reason for the learners' shortcomings. The society wants to see the product of education, which in many cases it is disappointed. This situation is as a result of students not taking responsibility of their actions and inactions. Learners need to understand that they are the architect of their failure or success in academics. This stand-point will go a long way in helping students improve themselves and perform better academically.

\section{Clarification of Key Concepts}

- Locus of control: This term was formulated by Julian Rotter in the 1950s. The term is viewed as a psychological construct which explains the attributes of people about the outcome of events in their lives owing to their own personal (self) characteristics or traits or external forces beyond their control. In other words, locus of control refers to the belief people have about the results of events in their lives as being caused by them or other powerful others. It explains who is to be held responsible for the consequences of events or occurrences in people's lives. Consequently, Rotter (1966) divided these responsible forces into two: internal and external locus of control.

i. Internal Locus of Control (ILOC): This is a person's belief that he is absolutely responsible for the outcomes of events in his life. The person takes responsibility of the results of his/her actions or inactions and not given to chance or external powerful forces.

ii. External Locus of Control (ELOC): This is a person's belief that the results of events or occurrences in his/her life are as a result of luck, chance or other powerful external forces. The individual is never responsible for whatever happens in his or her life, resulting from his/her actions or inactions. 
iii. Maximization: This is derived from the word "Maximize", which is a verb. It means to increase or raise the level of something as much as possible. Therefore, in this context, it means to raise or increase the level of students' academic performance.

iv. Academic Performance: This simply means the output of learners academically. It means how they do academically.

\subsection{Some Features/Comments of Students with Internal Locus of Control}

Sequel to the definition of internal locus of control, the following are some of the features of students with this trait:

- I am the architect of my destiny.

- I did not do well. (when performance is below expectation)

- I need to work harder.

- I have no excuse.

- I tried, but I need to do better.

- It is my fault.

- I can make it.

- If others can make it, then I can too.

- The teacher/lecturer tried. He or she is not to blame.

- Nothing can stop me from making it. Etc.

\subsection{Some Features/Comments of Students with External Locus of Control}

- Whatever God says will be will be. So, why do I kill myself?

- The lecturer gave me an F, E or, a D in that course.

- I made a B or an A.

- The lecturer failed me because I refused his proposal.

- I was not lucky enough.

- That course is very difficult.

- The semester was too short for me.

- Things are very hard for me.

- I tried my best.

- Whether I read or not, I can still make it.

- All works and no play makes Jack a dull boy.

- There are many ways of killing a rat. So, academic success does not only come through reading.

\subsection{Advancement of Internal Locus of Control as A Better Option for Improving Students'} Academic Performance

Kutamis, Mesci and Ovdur (2011) examined the effect of locus of control on students' learning performance and discovered that learning performance of students with an internal locus of control was higher than those with external locus of control. Furthermore, they also discovered that students with internal locus of control were more proactive and effective during the learning process. The students characterized by external locus of control were more passive during the teaching-learning process.

According to Jarrin, Kang and Aike (2017) cited in Mohamed, Mohamed and Ahmed (2018), the pathway to improve students' academic performance is training to develop their internal locus of control. 
Students with external locus of control view themselves as being powerless and helpless, since whatever is the outcome of their academic engagement is by luck and chance. Therefore, they are alienated from self-responsibility. Such a disposition of not taking full responsibility of one's academic output is not worth-recommending for anybody in academics. A critical consideration of both loci has revealed that students who view their academic performance as a matter of luck and chance will not do well academically. For instance, if a student feels that "whatever will be will be", such a student will rely on fate. He or She does not have any reason to study. Such a student will always be insensitive to his or her academics. This disposition will not enhance better academic performance.

A student who knows that he or she is the architect of his or her academic destiny will take full responsibility of his/her academics. This disposition will push him/her to study very hard in order to do better academically. Furthermore, a student who always says "I need to work harder" will always strive to improve his or her academic record. For instance, if his/her CGPA in YR 2 is 4.4, he will want to climb to 4.6 in YR 3 and possibly 4.8 in YR 4 in a four years programme. Such a student will not give room for complacency. Furthermore, if a student always says "I can make it", it means that such a student knows that there is nothing limiting him or her from achieving his or her academic goals. A student who does not see his/her teacher, environment, etc as obstacles to his/her academic excellence will be focused and determined.

Students with internal locus of control will have more academic substance than those with external locus of control. They are always more serious than those with external locus of control. They do not look for people to blame or accuse for their academic misfortune or failure. If they are not doing well, they blame themselves and look for ways to improve their performance. Also, if they are doing well, they want to do better.

Below is an academic performance scale of students with internal and external loci of control:

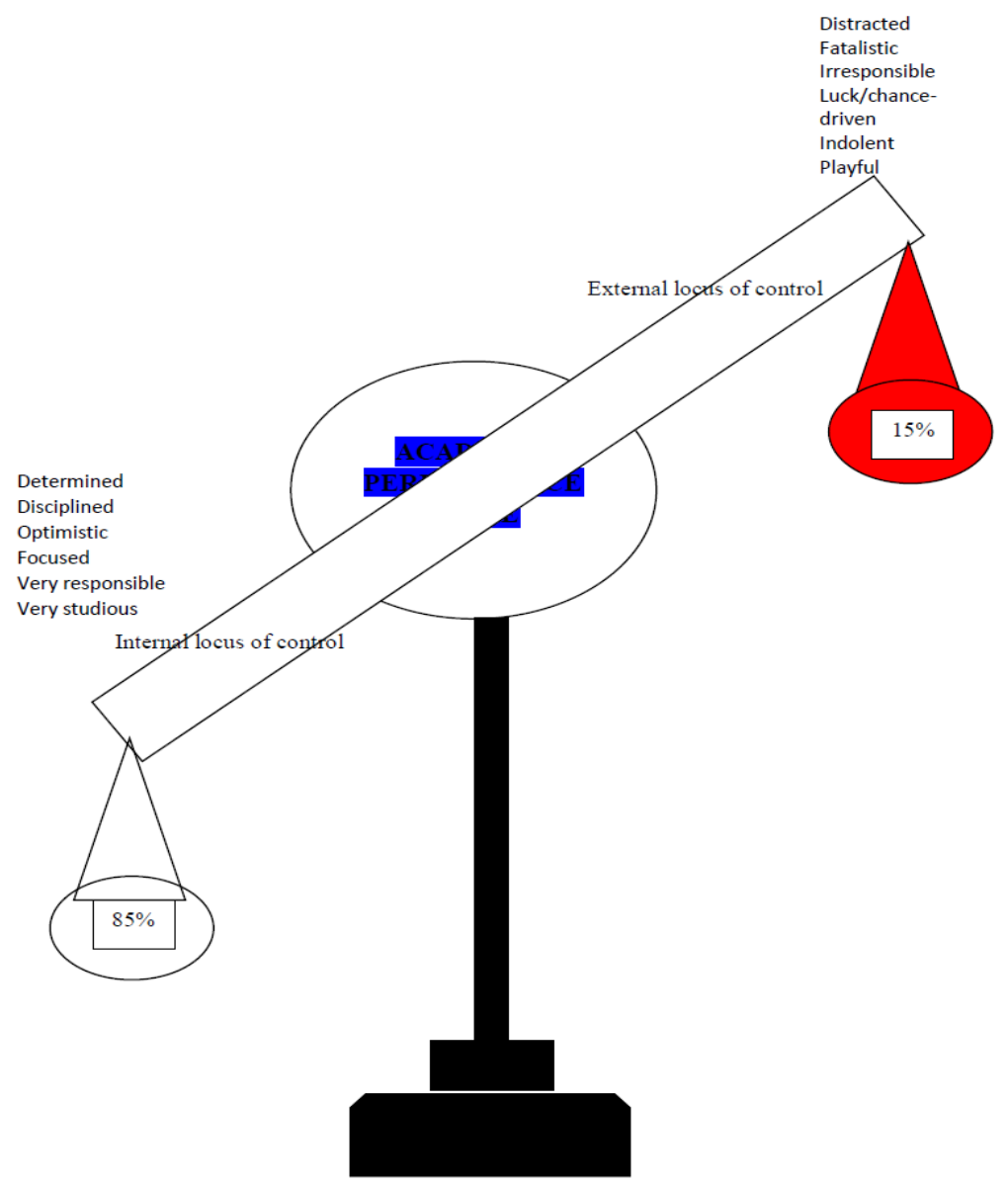

From the academic performance scale presented above, it is clear that students with internal locus of control have more weight than those with external locus of control. The contents of students with internal locus of control are by far higher than those with external locus of control. 
This paper advocates that internal locus of control is better than external locus of control in academics. Students' academic performance can be enhanced when students are made to see themselves as being responsible for their academic success or failure. They should be made to understand that they are the architect of their academic fortune or misfortune. This stance keeps every student under check.

\subsection{The Teacher as a Major Stakeholder in Enforcing the Internal Locus of Control for Maximizing Students' Academic Performance}

Izuagba (2012) noted that the teacher factor is an important index in the teaching-learning process because what he/she does or fails to do has a lot of implications on the learners' ability to achieve set goals. This goes to underscore the fact that the teacher is a major stakeholder in the teaching-learning process. The teacher is the primary implementer of any curriculum; therefore, responsibility is placed on the teacher to make his or her students take responsibility of the outcome of their academics. It is the duty of the teacher to instill in the learners that their output academically is very important and must not be trivialized. Therefore, they should wake up to their duty. They should make sure that they study hard to do well and better academically. This is in line with the advancement of Abid, Kanwal, Nasir, Iqbal and Ul-Huda (2016), who said that locus of control affects internally and externally in high ability students. Furthermore, that achieving prizes or losing prizes is like academic illness. Also, that carelessness affects students' academic performance. It means that students who are careless like those characterized by external locus of control will lose prizes and their academic performances are mostly negatively or adversely affected.

\section{CONCLUSION}

External and internal loci of control affect students' academic performance. Internal locus of control helps students to take full responsibility of their academic performance. Therefore, students should be made to build internal locus of control, as it will enhance their performance academically. Students with internal locus of control are always found performing better than those with external locus of control. It is expectant to let students understand that they are the architect of their academic destiny.

\section{RECOMMENDATIONS}

This paper recommends that:

1. Teachers should ensure that leaners at all levels develop internal locus of control.

2. Learners at all levels should understand that they are the architect of their academic fortune or misfortune.

\section{REFERENCES}

[1] Abid, M.A, Kanwal, S., Nasir, M.A, Iqbal, S. \& Ul-Hudu, V. (2016). The effect of locus of control on academic performance of the students at tertiary level. International Review of Management and Business Research, 5(3), 860-869

[2] Izuagba, A.C. (2012). Effective Teaching: Principles and Practice: Divine Mercy Publishers

[3] Kutamis, R., Mesci, M. \&Ovdur, Z. (2011). The effects of locus of control on leaning performance: A case of an academic organization. Journal of Economic and Social Studies, 1(2). 113-133

[4] Mohamed, A.A., Mohamed, A.M. \& Ahmed, H.A. (2018), Relationship between locus of control and academic achievement of nursing students at Damanhour University. Journal of Nursing and Health Science, 7(5), 1-13

Citation: Alfred, Dakoru Osomkume (Ph.D), Uduak Idoghor. "Internal Vs External Locus of Control: The Better Option for Maximization of Students' Academic Performance" International Journal of Humanities Social Sciences and Education (IJHSSE), vol 7, no. 4, 2020, pp. 171-174. doi: http://dx.doi.org/10.20431/2349. 0381.0704017 .

Copyright: (1) 2020 Authors. This is an open-access article distributed under the terms of the Creative Commons Attribution License, which permits unrestricted use, distribution, and reproduction in any medium, provided the original author and source are credited. 